\section{New Building for Horticulture at the U.S. Department of Agriculture/Agricultural Research Service in Beltsville, Maryland}

"There are nine stacks on the top. It looks like the Titanic. I hope it will not go down when we move in" one scientist remarked at the dedication ceremony for the new building. More knowledgeable scientists discounted his remarks because there is no evidence in the existing literature for icebergs in Maryland.

\section{THE BUILDING}

A new $6200-\mathrm{m}^{2}$ Plant Sciences Building was constructed at the Beltsville Agricultural Research Center(BARC), Beltsville, Md., and will house the Fruit Laboratory and the Vegetable Laboratory of the Plant Sciences Institute and the Floral and Nursery Plants Research Unit of the U.S. National Arboretum. It will be the home for 29 scientists and support personnel. The building is located on the campus of BARC between existing buildings and greenhouses.

The location of the building has inspired its style. The front is red brick to blend with the existing buildings around it (cover photo). The back of the building is all glass to pick up the mood of a large expanse of glass on the top of the greenhouses. Fortunately, this arrangement allowed the location of the laboratories on the glass side, with ample window space in each room. The support rooms (tissue culture, radioisotope, electron microscope, cold rooms, etc.) are across the hallway on the solid brick side.

The building is built to Occupational Safety and Health Administration specifications that require 10 to 12 air exchanges per hour in every laboratory room. Under such standards, the building not only was expensive to build but also is expensive to operate. To decrease the cost of operation, the offices were separated from the laboratories and placed into two office towers on the two ends of the building (Fig. 1). This arrangement allows recirculation of air in the offices and full air exchanges in the center block where the laboratories are located. The building is four stories high with three devoted to laboratories and offices and the fourth for air-handling machinery. To maximize the space within the building, exhaust flues for the chemical hoods were placed outside of the building (Fig. 2). These upright

Received for publication 28 Dec. 1994. Accepted for publication 3 Jan. 1995. The cost of publishing this paper was defrayed in part by the payment of page charges. Under postal regulations, this paper therefore must be hereby marked advertisement solely to indicate this fact.

Front cover: Front view of Plant Sciences Building, Beltsville, Md. Photo credit: ARS/USDA. Photographer: Scott Bauer. Pompidou building in Paris. houses will be interconnected.

\section{HISTORY} search remained in these buildings. stainless steel conduits, commonly referred to as "coffee cup handles," give the building an appearance somewhat reminiscent of the

Not far from the building, a large greenhouse complex is being modernized and will be ready this year. The building and the modern $3400-\mathrm{m}^{2}$ greenhouse complex will be connected with a $1400-\mathrm{m}^{2}$ facility that will house 76 growth chambers. The construction of the growth chamber facility is planned to start within 1 year, as soon as the design is completed. The entire complex, the new building, the growth chamber complex, and the green-

Horticultural research has a long history at Beltsville and its predecessor locations. When the U.S. Dept. of Agriculture's research was established, plant research and horticultural activities were located within Washington, D.C., on the Mall, near the area where the Washington monument is located. Plant research was moved in 1910 to Arlington, Va., where the Pentagon parking lots are now located, and in 1934 to Beltsville where the buildings housing fruit, vegetable, and ornamental research (Building 004) and postharvest research (Building 002) were constructed first. For the past 60 years, horticultural re-

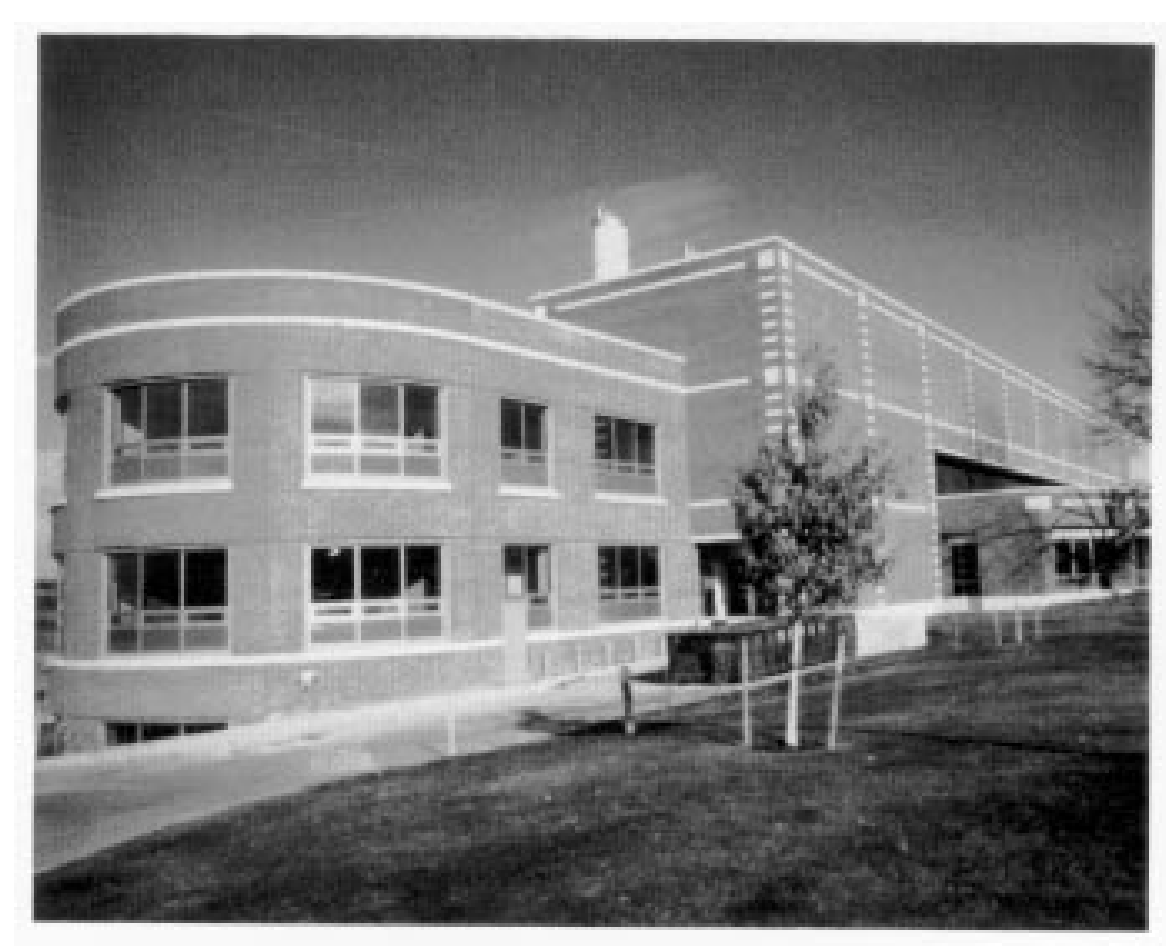

Fig. 1. South view of the building with the south office tower in the foreground.

The names of many horticulturists who worked at Beltsville are instantly recognized by people in the profession throughout the world. Names such as Frederick Coville, John Magness, George Darrow, Frank Cullinan, Don Scott, Cornelius Shear, Arlen Draper, L.C. Cochran, and Howard Brooks, in fruit research; Victor Boswell, A. Kehr, Ray Webb, and Allan Stoner in vegetable research; and Sam Elmsweller, Neil Stuart, Sam Asen, Robert Stewart, H. Marc Cathey, and Toru Arisumi in ornamental research. Countless accomplishments, too long to list, resulted from the work of these people. Beltsville, or its predecessor organizations, also provided 12 of the 82 ASHS presidents, further signifying the excellence of horticultural research conducted here.

\section{THE RESEARCH}

Although the research in the Fruit Laboratory involves several fruits, emphasis in the future will be placed on small-fruit research. The scientific staff of the Fruit Laboratory is currently 1) developing new physiological types of small fruit through germplasm enhancement and molecular biology methods; 2) adapting fruits to unique soil conditions by root system studies and biochemistry/nutritional relationships; 3) studying infective processes of fruit pathogens and molecular biological relationships among phytopathogenic bacteria affecting fruit trees; 4) developing new fruit-producing systems based on tissue culture propagation and cultural techniques, and 5) assessing the risk of industrial byproduct use and co-use with organic byproducts in fruit production systems. The molecular biology research on bacterial diseases mostly involves citrus diseases, and the

(continued on p. 410) 
molecular genetics of blueberry involves genetic manipulation of a plant's cold requirement to enable it to resume growth in more southern, warmer climates. The Fruit Laboratory has a wide-ranging cooperative research activity. The small-fruit improvement and the tissue culture propagation programs involve multistate cooperators. The citrus plant pathogen project involves international as well as national cooperation. The industrial by-product/co-use program involves several Agricultural Research Service locations and direct ties with industry. The Fruit Laboratory also has close ties with associations of growers who produce small fruit to enhance technology transfer and coordinate long- and shortterm research activities.

The mission of the Vegetable Laboratory is to improve the quality, pest resistance, and environmental adaptability of major vegetable crops. The Laboratory is conducting research to 1) develop and release new pest- and disease-resistant, high-quality germplasm and cultivars of major vegetables, especially potato and tomato; 2) understand mechanisms and inheritance of plant resistance to pathogens, insect pests, and environmental stresses in major vegetables; 3 ) improve resistance to disease, pests, and environmental stress in potato and tomato, and develop new breeding strategies and gene transfer techniques and establish their usefulness in vegetable improvement; 4) develop information on the biology and population dynamics of insect pests of vegetable crops, especially the Colorado potato beetle; 5) develop potato germplasm that has improved nutritional quality and contains minimal amounts of natural toxicants; 6) develop tomato germplasm that has improved solids for processing and improved flavor and nutritional value for the consumer;

\section{FIG. 2, HALFTONE SHOOT at $79 \%$}

\section{BLACK \& WHITE CROP AS SHOWN}

\section{DROP KEYLINE}

Fig. 2. The back of the building with the chemical hood flues.

and 7) develop environmentally safe cultural practices to improve production efficiency and income for low-input vegetable farms and assure the sustainability of vegetable production.

The Floral and Nursery Plants Research Unit of the U.S. National Arboretum conducts a broad-based program contributing to basic and developmental research and the implementation of new technologies for the florist and nursery industries. Emphasis is placed on developing new and superior floral and woody nursery plants. Research is focused on 1) interspecific and intraspecific hybridization; 2) developing virus-resistant plants through incorporation of viral gene and antiviral antibody gene products into the host plant; 3) developing new methods for detecting plant pathogens using serological and nucleic acid-based techniques; 4) improving methods of genetic transformation for crop improvement; 5) investigating processes of cell cycle regulation and differentiation; 6) developing new methods of pest and disease control using natural products; and 7) developing improved control methods for western flower thrips and sweetpotato and greenhouse whiteflies. The group is also cooperating with others to develop and use neem (Azadirachta indica $\mathrm{A}$. Juss.) by-products for pest and disease control and to produce new monoclonal antibody reagents for virus detection and disease diagnosis. These research programs have been strongly supported through direct financial support from the floral industry. This cooperation and support has resulted in the introduction of several new floral crops. The unit has strong international ties with cooperators in several Asian and European countries.

Miklos Faust Fruit Laboratory Agricultural Research Service U.S. Dept. of Agriculture Beltsville, MD 20705 